\title{
Kajian Pengaruh Rasio ISP (Isolated Soy Protein) dan Tepung Tapioka terhadap Kualitas Fisik, Kimia dan Sensori Cilok Kering
}

\author{
Fatimah Karim, Titi Mutiara Kiranawati, Soenar Soekopitojo \\ Universitas Negeri Malang, Jl. Semarang No. 5 Malang, Jawa Timur, Indonesia \\ *Penulis korespondensi, Surel: titi.mutiara.ft@um.ac.id
}

Paper received: 01-04-2021; revised: 19-04-2021; accepted: 20-04-2021

\begin{abstract}
The ratio of tapioca and ISP to dry Cilok in this research used a completely randomized design (CRD) consisting of one factor with five levels of the ratio of tapioca and ISP with treatment (I1) 100: 0 percent, (I2) 80: 20 percent, (I3) 70: 30 percent, (I4) 60: 40 percent (I5) 50: 50 percent and was repeated three times. This study was conducted to determine the effect of the ISP's ratio and tapioca to physical tests including texture and color, chemical tests including moisture, protein and starch, sensory tests including texture, color, and aroma, and the dried cilok after rehydrated including texture, color, taste, and aroma, and determine the best rehydration time of dried cilok. The ratio of tapioca and ISP to dry Cilok did not have a significant effect on water content, but significantly affected protein and starch levels. The ratio of tapioca and ISP to dried Cilok significantly affected the physical properties of color (brightness, redness, and yellowness). The ratio of tapioca and ISP to dried Cilok after rehydration has a significant effect on the physical properties of color (brightness, redness, and yellowness). The results of the hedonic test of color, aroma, and texture of dried cilok is the most favorite value with treatment 70 percent: 30 percent. The results of color hedonic test of dried Cilok after being rehydrated is the most favorite value at 50 percent: 50 percent treatment. Aroma and taste are the most favorite value at 100 percent: 0 percent. Texture has the most favorite value in the treatment 70 percent: 30 percent. The best rehydration time for dried Cilok is soaking for 6 hours and boiling for 10 minutes.
\end{abstract}

Keywords: cilok; isolated soy protein; tapioca

\begin{abstract}
Abstrak
Cilok kering rasio tepung tapioka dan ISP (Isolated Soy Protein) dalam penelitian ini menggunakan rancangan acak lengkap (RAL) yang terdiri dari satu faktor dengan lima level yaitu rasio tepung tapioka dan ISP dengan perlakuan (I1) 100:0 persen, (I2) 80: 20 persen, (I3) 70: 30 persen, (I4) 60: 40 persen (I5) 50:50 persen dan diulang sebanyak tiga kali. Penelitian ini bertujuan untuk mengetahui pengaruh rasio ISP dan tepung tapioka terhadap uji fisik meliputi tekstur dan warna, uji kimia meliputi kadar air, kadar protein dan kadar pati, uji sensoris Cilok kering meliputi tekstur, warna dan aroma, serta Cilok kering setelah direhidrasi meliputi tekstur, warna, rasa dan aroma, serta menentukan waktu rehidrasi Cilok kering yang terbaik. Rasio tepung tapioka dan ISP pada Cilok kering tidak memberikan pengaruh yang nyata terhadap kadar air, tetapi berpengaruh nyata terhadap kadar protein dan pati. Rasio tepung tapioka dan ISP pada Cilok kering berpengaruh nyata terhadap sifat fisik warna (tingkat kecerahan, kemerahan dan kekuningan). Rasio tepung tapioka dan ISP pada Cilok kering setelah direhidrasi berpengaruh nyata terhadap sifat fisik warna (tingkat kecerahan, kemerahan dan kekuningan). Tingkat kesukaan warna, aroma dan tekstur Cilok kering memiliki nilai kesukaan tertinggi pada perlakuan 70 persen:30 persen. Tingkat kesukaan warna Cilok kering setelah direhidrasi memiliki tingkat kesukaan tertinggi pada perlakuan 50 persen:50 persen. Aroma dan rasa memiliki tingkat kesukaan tertinggi pada perlakuan 100 persen: 0 persen. Tekstur memiliki tingkat kesukaan tertinggi pada perlakuan 70 persen: 30 persen. Waktu rehidrasi Cilok kering yang terbaik adalah perendaman selama 6 jam dan perebusan selama 10 menit.
\end{abstract}

Kata kunci: cilok; isolated soy protein (ISP); tepung tapioka 


\section{Pendahuluan}

Cilok atau aci dicolok adalah salah satu jajanan khas Kota Bandung yang berbentuk bulat, berbahan dasar kanji (aci) serta penyajiannya ditusuk (dicolok) menggunakan lidi (Solihat, 2016). Cilok pada umumnya berbahan dasar dari tepung tapioka dan berupa makanan semi basah (Anita, 2006). Sebagian besar Cilok dipasaran memiliki tekstur kenyal tetapi tidak elastis dan agak lengket serta memiliki kandungan protein tergolong rendah yaitu 4,2g/100g (Solihat, dkk., 2016; Wiraningrum, dkk. 2015).

Salah satu jenis bahan yang dapat meningkatkan kadar protein dan bisa sebagai bahan pembuatan Cilok adalah Isolated Soy Protein (Lestari, dkk., 2016). Komponen utama isolat protein kedelai adalah conglycinin (7S globulin) dan glycinin (11S globulin) yang berpengaruh terhadap kelarutan, water holding capacity (WHC), daya emulsi, daya buih, sifat gel dan kemampuan mengikat minyak atau lemak (Li, dkk., 2016; Andrew, dkk., 2006), dan berfungsi sebagai binder (pengikat) adonan, pengemulsi, gelling agent, meningkatkan cita rasa serta memberikan tekstur kenyal (Suryanto, 2011; Arifandy dan Adi, 2016). Cilok basah mempunyai kadar air sebesar 53,22\% sehingga memiliki daya simpan yang relatif rendah (Anita, 2006). Maka dari itu, untuk meningkatkan mutu produk Cilok agar masa simpan menjadi lebih lama adalah dengan membuat Cilok kering. Tujuan dari penelitian ini adalah sebagai inovasi baru dalam perbaikan kualitas Cilok, dari pengaruh raiso ISP (Isolated Soy Protein) dan tepung tapioka terhadap kualitas fisik, kimia dan sensori Cilok kering.

\section{Metode}

\subsection{Rancangan Penelitian}

Penelitian ini menggunakan metode eksperimental. Penelitian ini menggunakan rancangan acak lengkap (RAL) yang terdiri dari satu faktor dengan lima level yaitu rasio tepung tapioka dan ISP dengan perlakuan (I1) 100:0\%, (I2) 80: 20\%, (I3) 70: 30\%, (I4) 60: 40\% (I5) 50:50\% dan diulang sebanyak tiga kali. Penelitian ini dilakukan untuk mengetahui pengaruh rasio ISP dan tepung tapioka terhadap uji fisik meliputi tekstur dan warna, uji kimia meliputi kadar air, kadar protein dan kadar pati, uji sensoris Cilok kering meliputi tekstur, warna dan aroma, serta Cilok kering setelah direhidrasi meliputi tekstur, warna, rasa dan aroma, serta menentukan waktu rehidrasi Cilok kering yang terbaik. Bahan yang digunakan untuk membuat Cilok kering rasio tepung tapioka dan ISP adalah tepung tapioka, ISP, bawang putih, lada, garam, STPP dan air. Alat yang digunakan untuk pembuatan Cilok kering rasio tepung tapioka dan ISP adalah baksom, timbangan desimal, timbangan digital, gelas ukur, sendok, mangkuk kecil, mixer dough, panci, oven, kompor, spatula dapat dilihat pada Tabel 1.

Tabel 1. Formula Cilok Kering Rasio Tepung Tapioka dan ISP

\begin{tabular}{llllll}
\hline \multirow{2}{*}{ Bahan } & \multicolumn{9}{l}{ Formulasi (\%) } \\
\cline { 2 - 6 } & I & II & III & IV & V \\
\hline Tepung tapioka & 100 & 80 & 70 & 60 & 50 \\
ISP & 0 & 20 & 30 & 40 & 50 \\
Bawang putih & 2,4 & 2,4 & 2,4 & 2,4 & 2,4 \\
Lada & 0,5 & 0,5 & 0,5 & 0,5 & 0,5 \\
Garam & 2,0 & 2,0 & 2,0 & 2,0 & 2,0 \\
STPP & 0,4 & 0,4 & 0,4 & 0,4 & 0,4 \\
Es dan air es & 120 & 120 & 120 & 120 & 120 \\
\hline
\end{tabular}

(Sumber: Anita (2006) dan modifikasi peneliti) 


\subsection{Data Penelitian}

Cilok kering dan Cilok kering setelah direhidrasi rasio tepung tapioka dan ISP dilakukan penelitian mencakup analisis sifat kimia meliputi kadar protein menggunakan metode semi mikro kjeldal (AOAC, 2016), kadar pati menggunakan metode direct acid hydrolysis (AOAC, 2016), kadar air menggunakan metode oven (AOAC, 2016), analisis sifat fisik Cilok kering meliputi warna menggunakan metode kolorimeter $\mathrm{L}^{*} \mathrm{a}^{*} \mathrm{~b}^{*}$ dan tekstur (hardness) menggunakan metode penetrometer serta analisis sifat fisik Cilok kering setelah direhidrasi meliputi warna menggunakan metode kolorimeter $\mathrm{L}^{*} \mathrm{a} \mathrm{b}^{*}$ dan tekstur (springiness) menggunakan metode texture profile analyzer, sifat oraganoleptik cilong kering meliputi warna, aroma dan tekstur serta Cilok kering setelah direhidrasi meliputi warna, aroma, tekstur dan rasa dengan menggunakan instrument penilaian dengan rentang skor 1-5. Skor 1 untuk nilai terendah dan skor 5 untuk nilai yang tertinggi.

\subsection{Analisis Data Penelitian}

Data yang diperoleh pada penelitian Cilok kering rasio tepung tapioka dan ISP adalah data analisis sifat kimia (protein, pati, air), sifat fisik Cilok kering dan Cilok kering setelah direhidrasi (tekstur dan warna). Data dianalisis secara statistik menggunakan ANOVA dengan taraf signifikansi $5 \%$. Nilai signifikansi $<0,05$ maka terdapat perbedaan yang nyata. Apabila terdapat perbedaan maka dilanjutkan menggunakan uji DMRT (Duncan's Multiple Range Test). Sifat sensori Cilok kering (warna, aroma dan tekstur) dan sifat sensori Cilok kering setelah direhidrasi (rasa, aroma, tekstur dan warna) data dianalisis menggunakan tingkat kesukaan menggunakan metode presentase.

\section{3. .Hasil dan Pembahasan}

\subsection{Hasil}

\subsubsection{Kadar Air, Kadar Protein dan Kadar Pati}

Kandungan kadar air, kadar protein dan kadar pati pada Cilok kering rasio tepung tapioka dan ISP diperoleh rerata data dan dapat dilihat pada Gambar 1.

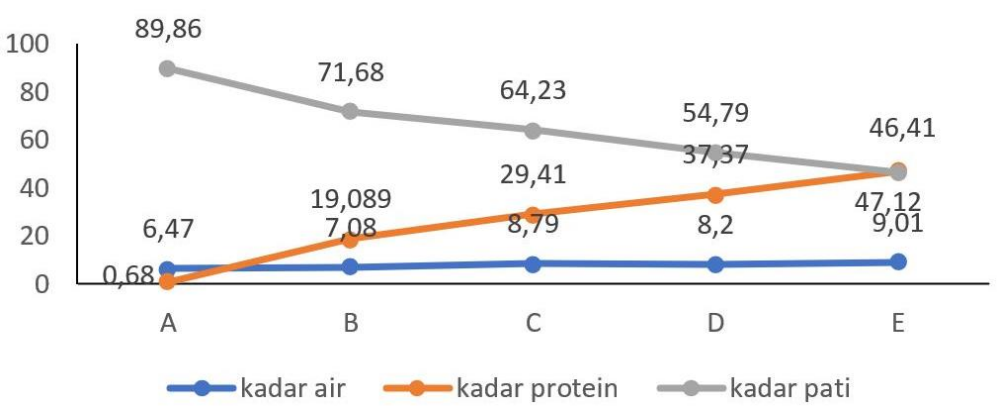

Gambar 1. Rerata Kadar Air, Kadar Protein dan Kadar Pati Cilok Kering Rasio Tepung Tapioka dan ISP

Keterangan:

A: Rasio tepung tapioka dan ISP 100: 0\%

B: Rasio tepung tapioka dan ISP 80: 20\%

C: Rasio tepung tapioka dan ISP 70: 30\%

D: Rasio tepung tapioka dan ISP 60: 40\% 


\subsubsection{Warna}

\subsubsection{Tingkat Kecerahan (L)}

Tingkat kecerahan pada Cilok kering rasio tepung tapioka dan ISP diperoleh rerata data dan dapat dilihat pada Tabel 2 .

Tabel 2. Rerata Warna Tingkat Kecerehan (L) Cilok Kering Hasil Penelitian dari Perlakuan Rasio Tepung Tapioka dengan ISP

\begin{tabular}{ccccc}
\hline Perlakuan & \multicolumn{3}{c}{ Pengulangan } & \multirow{2}{*}{ rerata } \\
\cline { 2 - 4 } Rasio Tapioka: ISP & $\mathbf{1}$ & $\mathbf{2}$ & $\mathbf{3}$ & \\
\hline 100\%:0\% & 49.3 & 50.6 & 49.4 & 49.8 \\
$80 \%: 20 \%$ & 50.1 & 50.4 & 49.5 & 50.0 \\
$70 \%: 30 \%$ & 47.7 & 46.0 & 47.4 & 47.0 \\
$60 \%: 40 \%$ & 45.6 & 45.8 & 43.8 & 45.1 \\
$50 \%: 50 \%$ & 43.2 & 43.7 & 44.2 & 43.7 \\
\hline
\end{tabular}

Tingkat kecerahan pada Cilok kering setelah direhidrasi rasio tepung tapioka dan ISP diperoleh rerata data dan dapat dilihat pada Tabel 3.

Tabel 3. Rerata Warna Tingkat Kecerehan (L) Cilok Kering Setelah Direhidrasi Hasil Penelitian dari Perlakuan Rasio Tepung Tapioka dengan ISP

\begin{tabular}{ccccc}
\hline \multirow{2}{*}{$\begin{array}{c}\text { Perlakuan Rasio } \\
\text { (Tapioka: ISP) }\end{array}$} & \multicolumn{3}{c}{ Pengulangan } & \multirow{2}{*}{ Rerata } \\
\cline { 2 - 4 } & $\mathbf{1}$ & $\mathbf{2}$ & $\mathbf{3}$ & \\
\hline 100\%:0\% & 41.3 & 42.2 & 41.9 & 41.8 \\
80\%:20\% & 39.5 & 40.3 & 39.9 & 39.9 \\
$70 \%: 30 \%$ & 44 & 45.9 & 44.4 & 44.8 \\
60\%:40\% & 45.1 & 44.5 & 44.3 & 44.6 \\
50\%:50\% & 42.8 & 42.5 & 42.7 & 42.7 \\
\hline
\end{tabular}

\subsubsection{Tingkat Kemerahan (+a)}

Tingkat kemerahan pada Cilok kering rasio tepung tapioka dan ISP diperoleh rerata data dan dapat dilihat pada Tabel 4.

Tabel 4 Rerata Warna Tingkat Kemerahan (+a) Cilok Kering Hasil Penelitian dari Perlakuan Rasio Tepung Tapioka dengan ISP

\begin{tabular}{ccccc}
\hline \multirow{2}{*}{$\begin{array}{c}\text { Perlakuan Rasio } \\
\text { (Tapioka: ISP) }\end{array}$} & \multicolumn{3}{c}{ Pengulangan } & \multirow{2}{*}{ Rerata } \\
\cline { 2 - 4 } & $\mathbf{1}$ & $\mathbf{2}$ & $\mathbf{3}$ & \\
\hline 100\%:0\% & 16.5 & 16.7 & 15.9 & 16.4 \\
$80 \%: 20 \%$ & 17.7 & 17.1 & 17.3 & 17.4 \\
$70 \%: 30 \%$ & 17 & 16.9 & 17.2 & 17.0 \\
$60 \%: 40 \%$ & 18.6 & 19.1 & 19.5 & 19.1 \\
$50 \%: 50 \%$ & 19.6 & 19.9 & 20.1 & 19.9 \\
\hline
\end{tabular}

Tingkat kemerahan pada Cilok kering setelah direhidrasi rasio tepung tapioka dan ISP diperoleh rerata data dan dapat dilihat pada Tabel 5. 
Tabel 5 Rerata Warna Tingkat Kemerahan (+a) Cilok Kering Hasil Penelitian dari Perlakuan Rasio Tepung Tapioka dengan ISP

\begin{tabular}{ccccc}
\hline \multirow{2}{*}{$\begin{array}{c}\text { Perlakuan Rasio } \\
\text { (Tapioka: ISP) }\end{array}$} & \multicolumn{3}{c}{ Pengulangan } & \multirow{2}{*}{ Rerata } \\
\cline { 2 - 4 } & $\mathbf{1}$ & $\mathbf{2}$ & $\mathbf{3}$ & \\
\hline 100\%:0\% & 12.6 & 12.7 & 12.0 & 12.4 \\
$80 \%: 20 \%$ & 14.6 & 13.5 & 14.7 & 14.3 \\
$70 \%: 30 \%$ & 15.3 & 15.6 & 16.1 & 15.7 \\
$60 \%: 40 \%$ & 16.6 & 15.9 & 15.7 & 16.1 \\
$50 \%: 50 \%$ & 16.4 & 16.8 & 16.5 & 16.6 \\
\hline
\end{tabular}

\subsubsection{Tingkat Kekuningan (+b)}

Tingkat kekuningan pada Cilok kering rasio tepung tapioka dan ISP diperoleh rerata data dan dapat dilihat pada Tabel 6.

Tabel 6. Rerata Warna Tingkat Kekuningan (+b) Cilok Kering Hasil Penelitian dari Perlakuan Rasio Tepung Tapioka dengan ISP

\begin{tabular}{ccccc}
\hline \multirow{2}{*}{$\begin{array}{c}\text { Perlakuan Rasio } \\
\text { (Tapioka: ISP) }\end{array}$} & \multicolumn{3}{c}{ Pengulangan } & \multirow{2}{*}{ Rerata } \\
\cline { 2 - 4 } & $\mathbf{1}$ & $\mathbf{2}$ & $\mathbf{3}$ & \\
\hline 100\%:0\% & 18.9 & 19.1 & 19.7 & 19.2 \\
$80 \%: 20 \%$ & 21.7 & 20.9 & 21.8 & 21.5 \\
$70 \%: 30 \%$ & 23.3 & 23.5 & 24 & 23.6 \\
60\%:40\% & 25.6 & 25 & 25.1 & 25.2 \\
50\%:50\% & 24.4 & 24.3 & 25.6 & 24.8 \\
\hline
\end{tabular}

Tingkat kekuningan pada Cilok kering setelah direhidrasi rasio tepung tapioka dan ISP diperoleh rerata data dan dapat dilihat pada Tabel 7.

Tabel 7. Rerata Warna Tingkat Kekuningan (+b) Cilok Kering Setelah Direhidrasi Hasil Penelitian dari Perlakuan Rasio Tepung Tapioka dengan ISP

\begin{tabular}{ccccc}
\hline Sampel & \multicolumn{3}{c}{ Pengulangan } & \multirow{2}{*}{ Rerata } \\
\cline { 2 - 4 } (Tapioka: ISP) & $\mathbf{1}$ & $\mathbf{2}$ & $\mathbf{3}$ & \\
\hline 100\%:0\% & 15.7 & 15.5 & 15.1 & 15.4 \\
80\%:20\% & 18.2 & 17.9 & 18.1 & 18.1 \\
$70 \%: 30 \%$ & 20.3 & 21.6 & 21.7 & 21.2 \\
$60 \%: 40 \%$ & 20.1 & 19.5 & 20.3 & 19.9 \\
$50 \%: 50 \%$ & 20.4 & 20.2 & 21.2 & 20.6 \\
\hline
\end{tabular}

\subsubsection{Tekstur}

\subsubsection{1. (Kekerasan) Hardness}

Tingkat kekerasan (hardness) Cilok kering rasio tepung tapioka dan ISP diperoleh rerata data dan dapat dilihat pada Tabel 8. 
Tabel 8. Rerata Sifat Fisik Tekstur (Hardness) Cilok Kering Hasil Penelitian dari Perlakuan Rasio Tepung Tapioka dengan ISP

\begin{tabular}{ccccc}
\hline \multirow{2}{*}{$\begin{array}{c}\text { Perlakuan Rasio } \\
\text { (Tapioka: ISP) }\end{array}$} & \multicolumn{3}{c}{ Pengulangan (Kgf) } & Rerata \\
\cline { 2 - 4 } & $\mathbf{1 ~ ( K g f ) ~}$ & $\mathbf{2}$ (Kgf) & $\mathbf{3 ~ ( K g f ) ~}$ & (Kgf) \\
\hline 100\%:0\% & 18.595 & 19.172 & 18.154 & 18.640 \\
$80 \%: 20 \%$ & 15.821 & 14.814 & 15.889 & 15.508 \\
$70 \%: 30 \%$ & 11.927 & 11.226 & 12.678 & 11.944 \\
$60 \%: 40 \%$ & 13.626 & 10.541 & 12.069 & 12.079 \\
50\%:50\% & 14.072 & 13.512 & 13.335 & 13.639 \\
\hline
\end{tabular}

\subsubsection{2. (Kekenyalan) Springiness}

Tingkat kekenyalan (springiness) Cilok kering setelah direhidrasi rasio tepung tapioka dan ISP diperoleh rerata data dan dapat dilihat pada Tabel 9.

Tabel 9. Rerata Sifat Fisik Tekstur (Springiness) Cilok Kering Setelah Direhidrasi Hasil Penelitian Perlakuan dari Rasio Tepung Tapioka dengan ISP

\begin{tabular}{ccccc}
\hline Perlakuan Rasio & \multicolumn{3}{c}{ Pengulangan } & Rerata \\
\cline { 2 - 4 } (Tapioka: ISP) & $\mathbf{1}$ & $\mathbf{2}$ & $\mathbf{3}$ & (mm) \\
\hline $100 \%: 0 \%$ & 0.94 & 0.78 & 0.77 & 0.83 \\
$80 \%: 20 \%$ & 0.92 & 1.15 & 0.59 & 0.89 \\
$70 \%: 30 \%$ & 0.85 & 1.01 & 0.82 & 0.89 \\
$60 \%: 40 \%$ & 0.89 & 0.96 & 0.79 & 0.88 \\
$50 \%: 50 \%$ & 1.31 & 1.29 & 1.07 & 1.22 \\
\hline
\end{tabular}

\subsubsection{Hedonik Warna}

Hasil rerata skor kesukaan panelis terhadap warna Cilok kering rasio tepung tapioka dan ISP dapat dilihat pada Gambar 2.

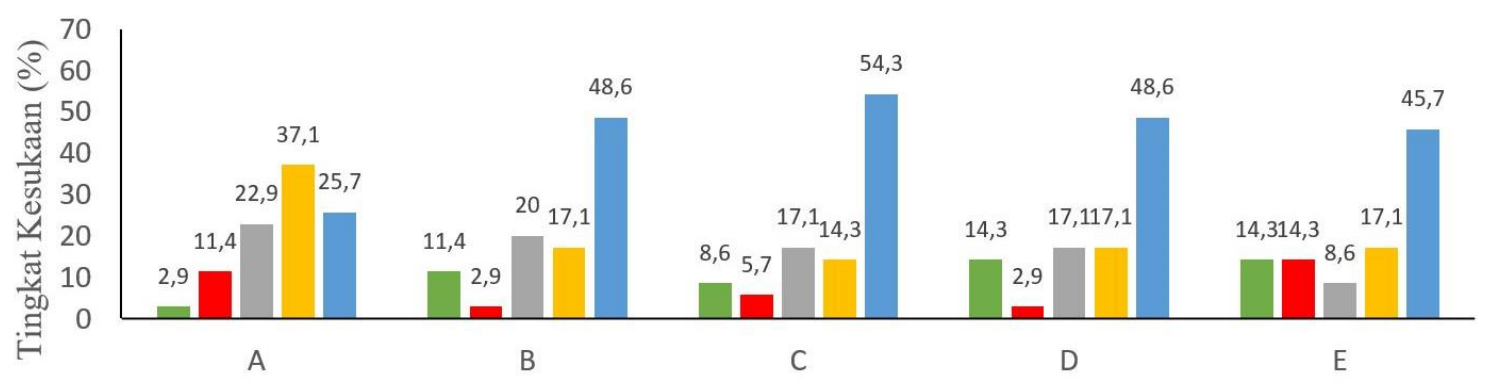

Gambar 2. Tingkat Kesukaan Warna Cilok Kering Hasil Penelitian Perlakuan dari Rasio

Keterangan:

A: Rasio tepung tapioka dan ISP 100: 0\%

B: Rasio tepung tapioka dan ISP 80: $20 \%$

C: Rasio tepung tapioka dan ISP 70: $30 \%$

D: Rasio tepung tapioka dan ISP 60: 40\%

E: Rasio tepung tapioka dan ISP 50: 50\%

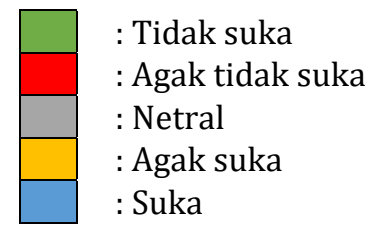

\subsubsection{Tepung Tapioka dan ISP}

Hasil rerata skor kesukaan panelis terhadap warna Cilok kering setelah direhidrasi rasio tepung tapioka dan ISP dapat dilihat pada Gambar 3. 


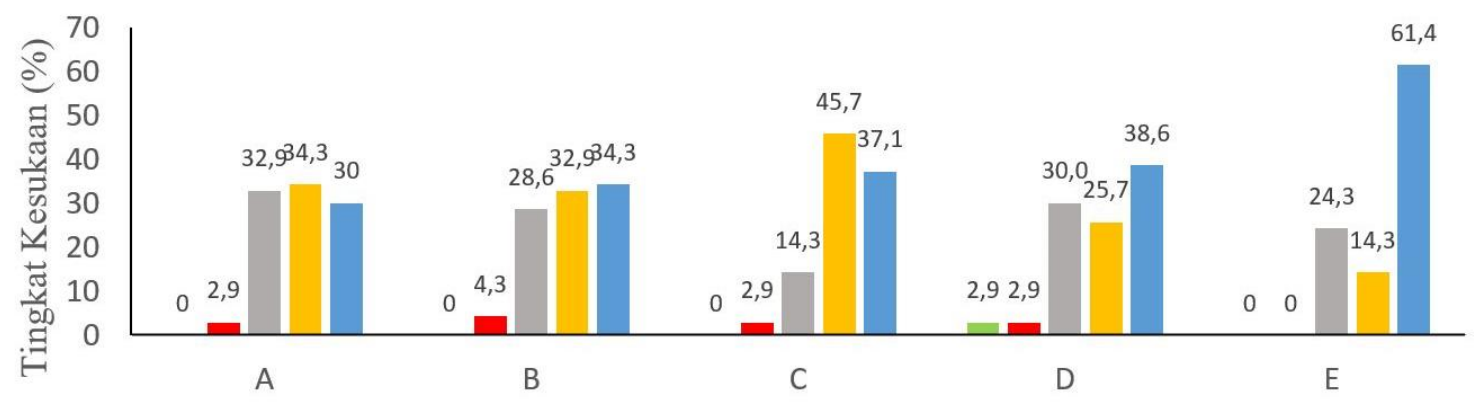

Gambar 3. Tingkat Kesukaan Warna Cilok Kering Setelah Direhidrasi Hasil Penelitian Perlakuan dari Rasio Tepung Tapioka dan ISP

Keterangan:

A: Rasio tepung tapioka dan ISP 100: 0\%

B: Rasio tepung tapioka dan ISP 80: $20 \%$

C: Rasio tepung tapioka dan ISP 70: 30\%

D: Rasio tepung tapioka dan ISP 60: 40\%

E: Rasio tepung tapioka dan ISP 50: 50\%

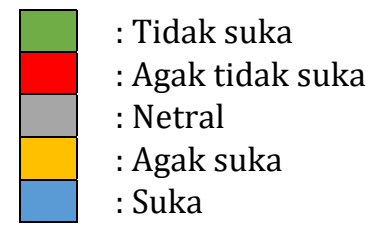

\subsubsection{Hedonik Aroma}

Hasil rerata skor kesukaan panelis terhadap aroma Cilok kering rasio tepung tapioka dan ISP dapat dilihat pada Gambar 4.

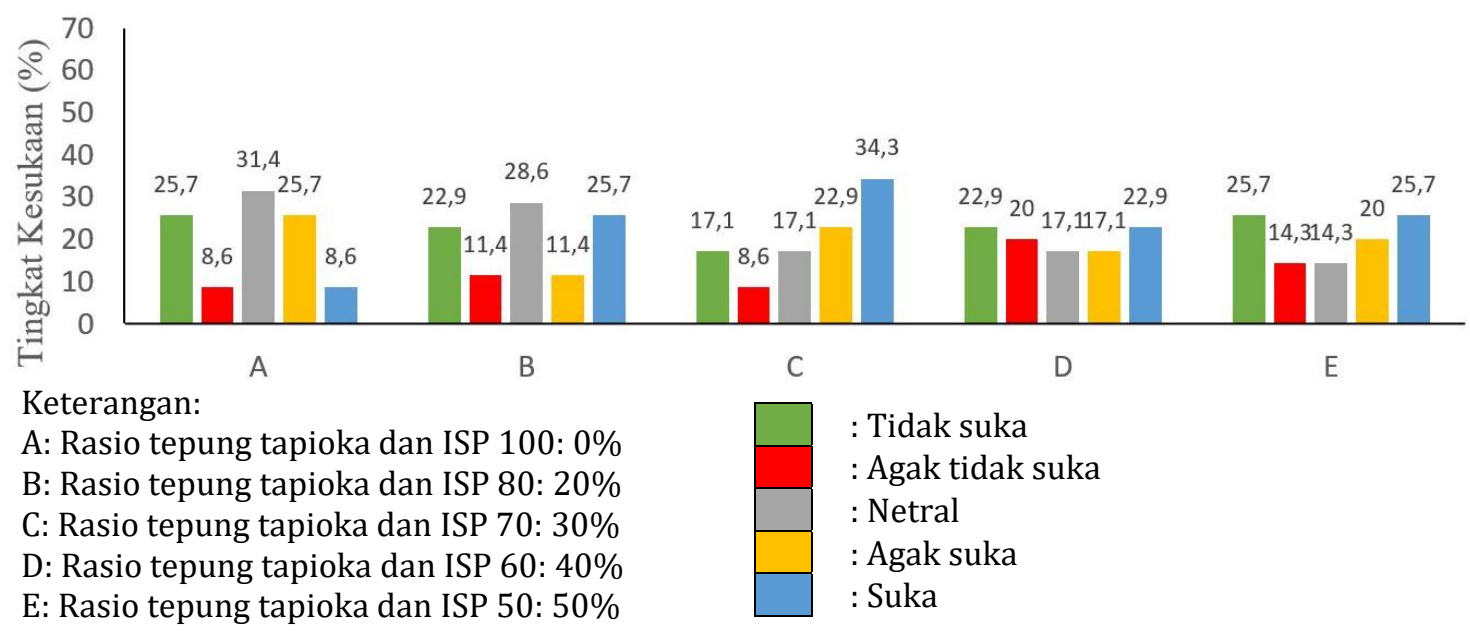

\section{Gambar 4. Tingkat Kesukaan Aroma Cilok Kering Hasil Penelitian Perlakuan dari Rasio Tepung Tapioka dan ISP}

Hasil rerata skor kesukaan panelis terhadap aroma Cilok kering setelah direhidrasi rasio tepung tapioka dan ISP dapat dilihat pada Gambar 5. 


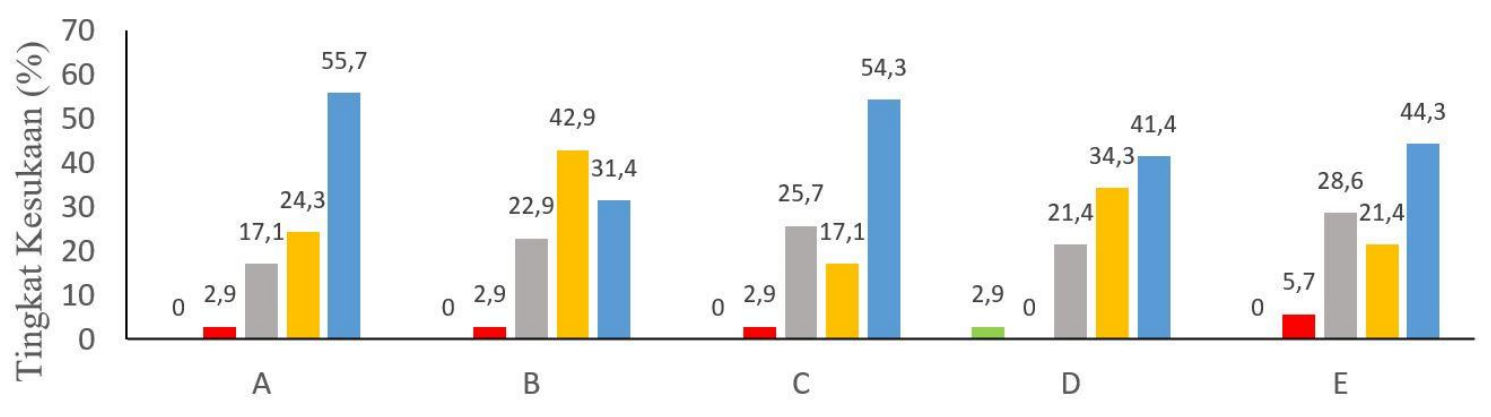

Gambar 5. Tingkat Kesukaan Aroma Cilok Kering Setelah Direhidrasi Hasil Penelitian Perlakuan dari Rasio Tepung Tapioka dan ISP

Keterangan:

A: Rasio tepung tapioka dan ISP 100: $0 \%$

B: Rasio tepung tapioka dan ISP 80: $20 \%$

C: Rasio tepung tapioka dan ISP 70: $30 \%$

D: Rasio tepung tapioka dan ISP 60: 40\%

E: Rasio tepung tapioka dan ISP 50: 50\%

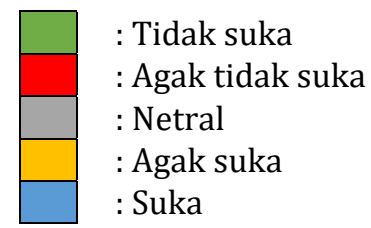

\subsubsection{Hedonik Tekstur}

Hasil rerata skor kesukaan panelis terhadap tekstur Cilok kering rasio tepung tapioka dan ISP dapat dilihat pada Gambar 6.

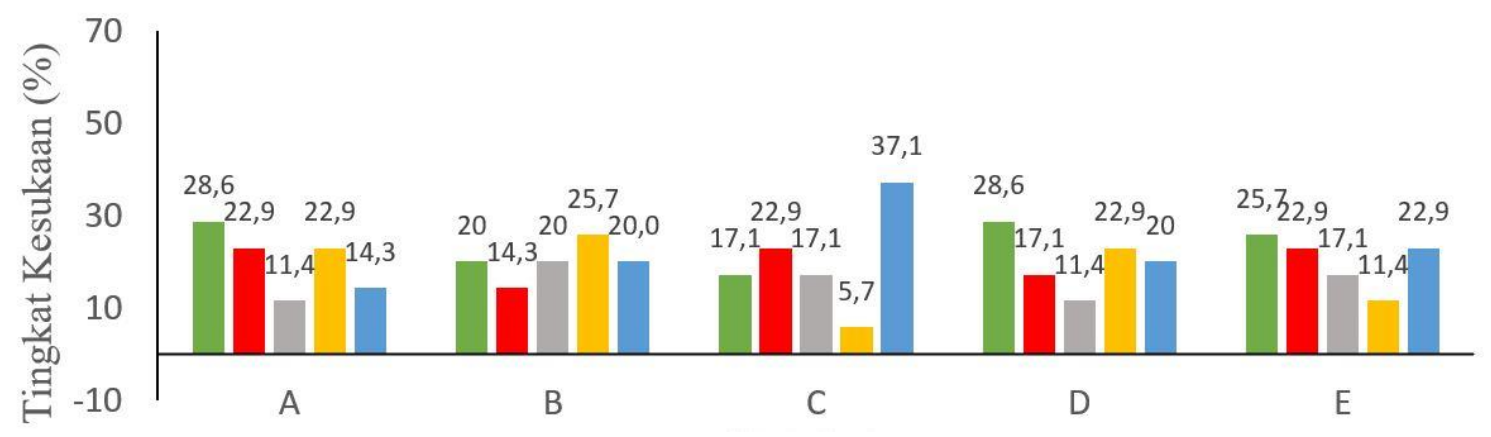

\section{Gambar 6. Tingkat Kesukaan Tekstur Cilok Kering Hasil Penelitian Perlakuan dari Rasio Tepung Tapioka dan ISP}

Keterangan:

A: Rasio tepung tapioka dan ISP 100: 0\%

B: Rasio tepung tapioka dan ISP 80: $20 \%$

C: Rasio tepung tapioka dan ISP 70: $30 \%$

D: Rasio tepung tapioka dan ISP 60: 40\%

E: Rasio tepung tapioka dan ISP 50: 50\%

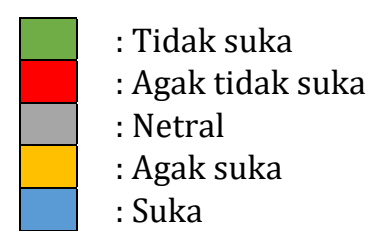

Hasil rerata skor kesukaan panelis terhadap tekstur Cilok kering setelah direhidrasi rasio tepung tapioka dan ISP dapat dilihat pada Gambar 7. 


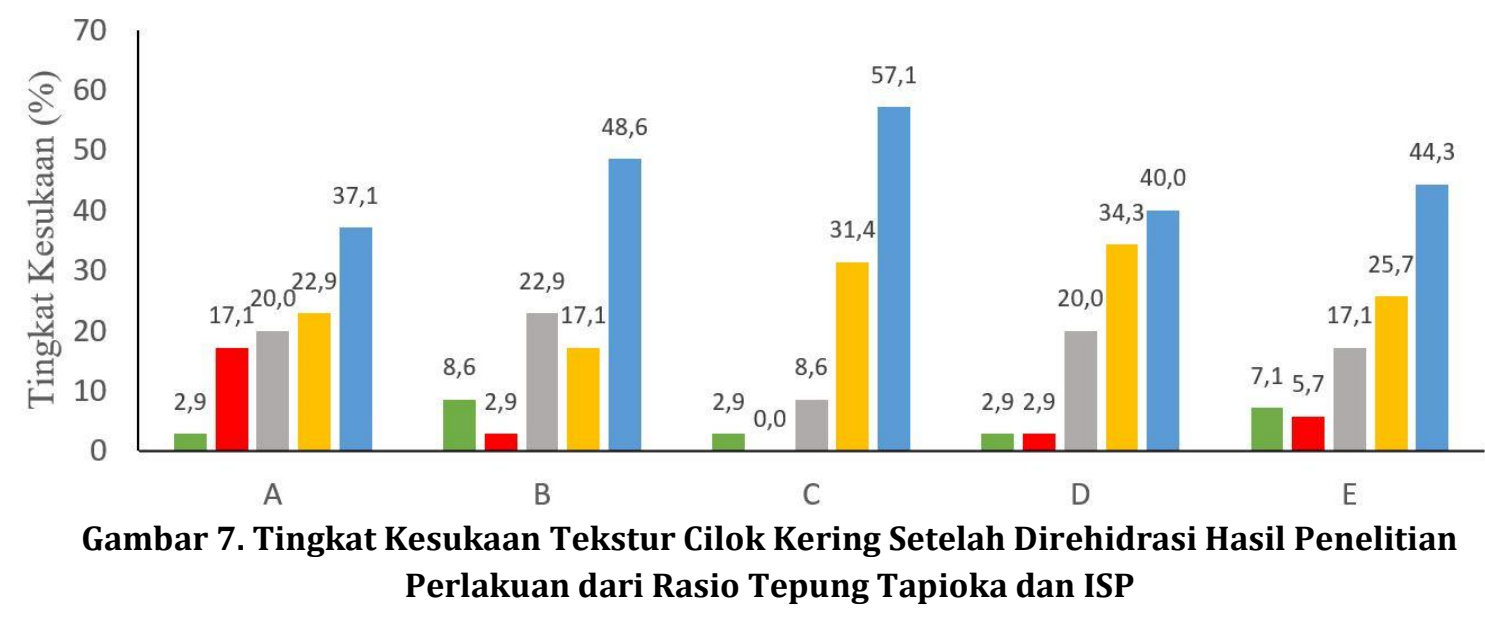

Keterangan:

A: Rasio tepung tapioka dan ISP 100: 0\%

B: Rasio tepung tapioka dan ISP 80: $20 \%$

C: Rasio tepung tapioka dan ISP 70: $30 \%$

D: Rasio tepung tapioka dan ISP 60: 40\%

E: Rasio tepung tapioka dan ISP 50: 50\%

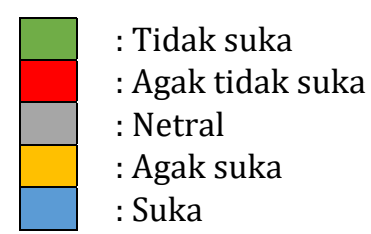

\subsubsection{Hedonik Rasa}

Hasil rerata skor kesukaan panelis terhadap rasa Cilok kering setelah direhidrasi rasio tepung tapioka dan ISP dapat dilihat pada Gambar 7.

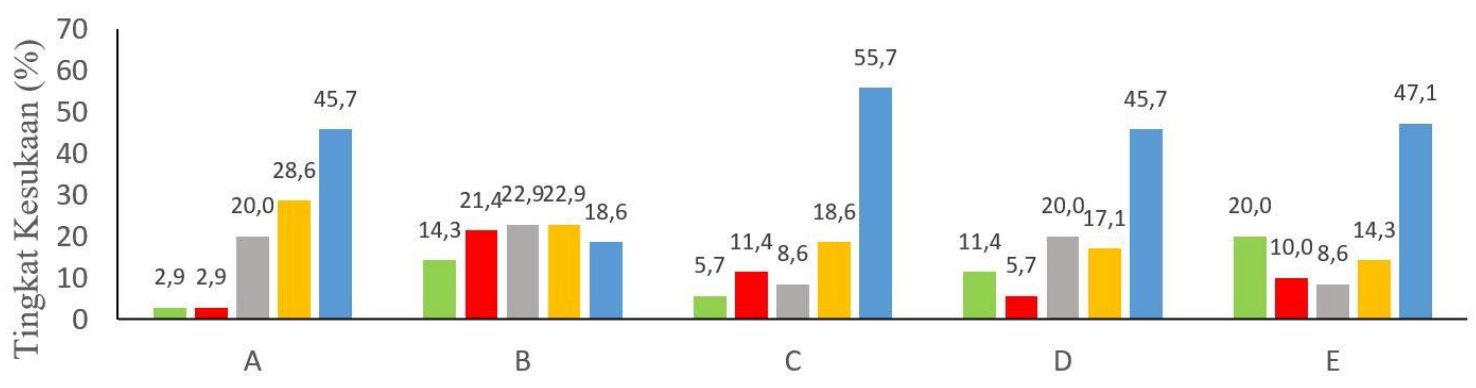

Gambar 8. Tingkat Kesukaan Rasa Cilok Kering Setelah Direhidrasi Rasio Tepung Tapioka dan ISP

Keterangan:

A: Rasio tepung tapioka dan ISP 100: 0\%

B: Rasio tepung tapioka dan ISP 80: $20 \%$

C: Rasio tepung tapioka dan ISP 70: $30 \%$

D: Rasio tepung tapioka dan ISP 60: 40\%

E: Rasio tepung tapioka dan ISP 50: 50\%

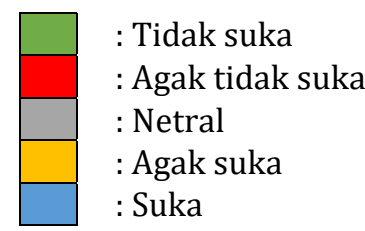

\subsubsection{Waktu Rehidrasi Pada Suhu Ruang}

Hasil rerata daya rehidrasi pada suhu ruang terhadap Cilok kering setelah direhidrasi hasil penelitian perlakuan dari rasio tepung tapioka dan ISP dapat dilihat pada Tabel 13. 
Tabel 10. Hasil Rerata Daya Rehidrasi pada Suhu Ruang Cilok Kering Setelah Direhidrasi Hasil Penelitian Perlakuan dari Rasio Tepung Tapioka dengan ISP

\begin{tabular}{ccccc}
\hline \multirow{2}{*}{ Perlakuan } & \multicolumn{4}{c}{ Waktu Perendaman (jam) } \\
\cline { 2 - 5 } & $\mathbf{2}$ & $\mathbf{4}$ & $\mathbf{6}$ & $\mathbf{8}$ \\
\hline $100 \%: 0 \%$ & 41.142 & 52.087 & 70.968 & 71.968 \\
$80 \%: 20 \%$ & 59.486 & 76.247 & 87.850 & 97.368 \\
$70 \%: 30 \%$ & 67.934 & 80.833 & 100.831 & 105.540 \\
$60 \%: 40 \%$ & 61.340 & 76.945 & 91.453 & 97.429 \\
$50 \%: 50 \%$ & 64.769 & 80.952 & 98.214 & 97.910 \\
\hline
\end{tabular}

\subsubsection{Waktu Rehidrasi Setelah Perendaman Pada Suhu Panas}

Hasil rerata daya rehidrasi pada suhu ruang Cilok kering setelah direhidrasi rasio tepung tapioka dan ISP dilihat pada Tabel 11.

Tabel 11. Hasil Rerata Daya Rehidrasi pada Suhu Ruang Cilok Kering Setelah Direhidrasi Hasil Penelitian Perlakuan dari Rasio Tepung Tapioka dengan ISP

\begin{tabular}{|c|c|c|c|c|}
\hline $\begin{array}{l}\text { Perlakuan } \\
\text { Rasio } \\
\text { Tapioka: } \\
\text { ISP } \\
\end{array}$ & $\begin{array}{l}\text { Lama } \\
\text { perendaman } \\
\text { (jam) }\end{array}$ & $\begin{array}{c}\text { Rerata Daya } \\
\text { Rehidrasi }\end{array}$ & $\begin{array}{c}\text { Rerata Waktu } \\
\text { Perebusan } \\
\text { (menit) }\end{array}$ & $\begin{array}{c}\text { Rerata Daya } \\
\text { Rehidrasi Setelah } \\
\text { Perebusan }\end{array}$ \\
\hline \multirow{4}{*}{ 100\%:0\% } & 2 & 41.142 & 50 & 69.488 \\
\hline & 4 & 52.087 & 30 & 82.803 \\
\hline & 6 & 70.968 & 10 & 83.871 \\
\hline & 8 & 71.968 & 4 & 85.288 \\
\hline \multirow{4}{*}{ 80\%:20\% } & 2 & 59.486 & 50 & 86.591 \\
\hline & 4 & 76.247 & 30 & 90.736 \\
\hline & 6 & 87.850 & 10 & 96.963 \\
\hline & 8 & 97.368 & 4 & 103.589 \\
\hline \multirow{4}{*}{$70 \%: 30 \%$} & 2 & 67.934 & 50 & 131.074 \\
\hline & 4 & 80.833 & 30 & 128.333 \\
\hline & 6 & 100.831 & 10 & 127.701 \\
\hline & 8 & 105.540 & 4 & 126.039 \\
\hline \multirow{4}{*}{$60 \%: 40 \%$} & 2 & 61.340 & 50 & 143.643 \\
\hline & 4 & 76.945 & 30 & 153.026 \\
\hline & 6 & 91.453 & 10 & 113.675 \\
\hline & 8 & 97.429 & 4 & 113.143 \\
\hline \multirow{4}{*}{ 50\%:50\% } & 2 & 64.769 & 50 & 146.619 \\
\hline & 4 & 80.952 & 30 & 151.488 \\
\hline & 6 & 98.214 & 10 & 118.750 \\
\hline & 8 & 97.910 & 4 & 118.507 \\
\hline
\end{tabular}

\subsection{Pembahasan}

\subsubsection{Kadar Air}

Kadar air Cilok kering hasil penelitian perlakuan dari rasio tepung tapioka dan ISP berkisar antara 6,473-9,017\%. Kadar air tersebut lebih kecil dibandingkan dengan kadar air pada bakso kering udang sebesar 10,25\% hasil penelitian Andriani (2018). Hasil analisis menunjukkan bahwa kadar air yang tidak berbeda nyata pada perlakuan dari rasio tepung tapioka dengan ISP pada pembuatan Cilok kering. Hal ini disebabkan oleh adonan Cilok yang 
tergelatinisasi sebelum dikeringkan mampu menahan air antara 140-146\%, terjadi kemiripan antar perlakuan Cilok yang dikeringkan pada suhu dan lama pengeringan yang sama antar perlakuan yaitu pada suhu $60^{\circ} \mathrm{C}$ selama $12 \mathrm{jam}$. Maka jumlah air yang teruapkan pada Cilok mirip, sehingga tidak berbeda nyata. Diduga air yang berada pada adonan Cilok berbentuk air bebas sehingga mudah untuk diuapkan, selain itu pengguaan rasio tepung tapioka dan ISP pada pembuatan Cilok kering dalam berbagai perlakuan tidak memberikan pengaruh yang nyata terhadap kadar air. Menurut Pangastuti, dkk. (2013) isolat protein kedelai mempunyai sifat hidrofilik (dapat mengikat air) dan hidrofobik (tidak dapat mengikat air).

\subsubsection{Kadar Protein}

Kadar protein Cilok kering tertinggi adalah $47,123 \%$ yaitu hasil perlakuan dari rasio tepung tapioka dan ISP 50\%:50\%. Kandungan protein Cilok kering terendah yaitu 0,682\% yaitu hasil perlakuan dari rasio tepung tapioka dan ISP 100\%:0\%. Semakin banyak penggunaan ISP pada pembuatan adonan Cilok kering maka cenderung semakin tinggi kandungan kadar protein Cilok kering, karena isolat protein kedelai memiliki kandungan protein lebih dari 90\% (Karl dan Bridget, 2009). Hal ini didukung dari penelitian yang dilakukan oleh Astuti (2014) penambahan ISP dapat meningkatkan kadar protein bakso ikan swangi. Selain itu menurut penelitian Wicaksana, dkk. (2014) penambahan ISP pada surimi ikan patin dapat meningkatkan kadar protein surimi. Cilok kering hasil penelitian perlakuan dari rasio tepung tapioka dengan ISP sebesar 50\%:50\% lebih besar dibandingan dengan kandungan protein pada produk serupa yaitu Cilok gajih sebesar 1,04\% (Anita, 2006), Cilok ikan lele sebesar 9,4/100g (Lestari dan Adi, 2016), surimi ikan kembung sebesar 32,50\% (Azizah dan Asma, 2018). Hal ini didukung dengan penelitian yang dilakukan oleh Astuti (2014) penambahan ISP dapat meningkatkan kadar protein bakso ikan swangi.

\subsubsection{Kadar Karbohidrat (Pati)}

Kandungan kadar pati Cilok kering tertinggi adalah 89,863\% yaitu hasil perlakuan dari rasio tepung tapioka dan ISP 100\%:0\%. Kandungan pati Cilok kering terendah adalah 46,416\% yaitu hasil perlakuan dari rasio tepung tapioka dan ISP 50\%:50\%. Semakin banyak penggunaan ISP pada pembuatan adonan Cilok maka semakin rendah kandungan kadar pati pada Cilok kering. Hasil penelitian kandungan pati Cilok kering dari semua perlakuan dari rasio tepung tapioka dengan ISP lebih besar dibandingkan dengan beberapa produk serupa seperti kadar pati Cilok gajih dipasaran sebesar 43,41\% (Anita, 2006), bakso kering udang rebon sebesar 33,328\% (Andriani, 2018), daging analog kacang merah substitusi ISP sebesar 31,1037,75\% (Utama, 2016). Kadar pati pada Cilok kering hasil penelitian menunjukkan bahwa, semakin rendah rasio penggunaan tepung tapioka pada adonan Cilok maka semakin rendah kandungan kadar pati pada Cilok kering. Hal tersebut terjadi karena tepung tapioka mengandung pati sebesar 88,01g/100g (Tabel 2.4), sehingga penggunaan tepung tapioka berbanding lurus dengan kadar pati pada Cilok kering.

\subsubsection{Warna}

\subsubsection{Tingkat Kecerahan (L)}

\subsection{Cilok Kering Rasio Tepung Tapioka dan ISP}


Hasil penelitian Cilok kering dari perlakuan rasio tepung tapioka dengan ISP, nilai rerata kecerahan (L) tertinggi adalah perlakuan dari rasio 80\%:20\% yaitu 50 dan nilai rerata kecerahan (L) terendah adalah perlakuan dari rasio 50\%:50\% yaitu 43,7. Cilok kering hasil penelitian hasil perlakuan dari rasio tepung tapioka dengan ISP menunjukkan bahwa, rasio 100\%:0 dan 80\%:20\% memiliki warna lebih cerah dibandingkan rasio 70\%:30\%, 60\%:40\% dan 50\%:50\%. Faktor yang menentukan kualitas dari tepung-tepungan adalah derajat putih. Dibandingkan dengan tepung tapioka, tepung ISP cenderung berwarna lebih gelap karena berbasis dari kacang kedelai. Nilai derajat putih tepung tapioka sebesar 86,5 (Widaningrum, dkk., 2005) dan tepung isolat protein kedelai sebesar 68,56 (Puteri, dkk., 2017). Selain itu, warna gelap pada cilok kering rasio tepung tapioka dan ISP didapatkan dari adanya reaksi antara karbohidrat yang bersumber dari tepung tapioka dan gugus amino dari ISP. Kedua senyawa tersebut apabila saling berinteraksi dengan adanya pemanasan maka akan menghasilkan senyawa melanoidin yang menyebabkan warna menjadi lebih gelap dan disebut reaksi maillard (Winarno, 2004). Sehingga semakin banyak penambahan ISP maka tingkat kecerahan Cilok akan semakin menurun. Hal tersebut didukung dengan penelitian Astuti, dkk., (2014) semakin tinggi penggunaan ISP maka semakin gelap bakso ikan swangi yang dihasilkan, hal tersebut dipengaruhi oleh penambahan ISP pada adonan.

\subsection{Cilok Kering Setelah Direhidrasi Rasio Tepung Tapioka dan ISP}

Tingkat kecerahan (L) Cilok kering setelah direhidrasi dipengaruhi oleh kemampuan Cilok kering perlakuan dari rasio tepung tapioka dengan ISP menahan air selama gelatinisasi pada proses rehidrasi. Hal ini mirip dengan hasil penelitian Li. (2005) tentang fraksi protein $11 \mathrm{~S}$ kedelai, yang membahas tentang hubungan antara tingkat kecerahan fraksi protein dengan lama gelatinisasi. Semakin tergelatinisasi sempurna air yang tertahan didalam bahan akan semakin banyak, sehingga tingkat kecerahan akan semakin kuat. Rerata daya rehidrasi Cilok kering tertinggi hasil penelitian pada perlakuan 70\%:30\% yaitu 127,701\% diikuti dengan perlakuan 50\%:50\% yaitu 118,750. Perlakuan 60\%:40\% yaitu 113,675\%. Perlakuan 80\%:20\% yaitu 96,963\%. Perlakuan 100\%:0\% yaitu 83,871. Berdasarkan hasil penelitian Cilok kering setelah direhidrasi, dari perlakuan rasio tepung tapioka dengan ISP memiliki nilai rerata kecerahan (L) tertinggi adalah 44,8 yaitu hasil perlakuan dari tepung tapioka dengan ISP rasio 70\%:30\%. Hal ini berbanding lurus dengan air yang tertahan dalam gel Cilok selama proses rehidrasi. Tertahannya air dalam cilok membuat rongga udara terisi air sehingga suatu bahan dapat memantulkan cahaya dari bahan tersebut terhadap cahaya yang mengenai permukaan (Indrasti, 2004). Perlakuan 50\%:50\% memiliki tingkat kecerahan (L) lebih gelap dibandingkan dengan perlakuan 60\%:40\% dan 70\%:30\% yaitu 42,8. Hal tersebut terjadi karena adanya reaksi pencoklatan non-enzimatis atau reaksi mailard. Selain itu, reaksi mailard berlangsung cepat karena dipengaruhi oleh proses pengolahan suhu tinggi seperti pemasakan (Kusnandar, 2010). Perlakuan 100\%:0\% memiliki tingkat kecerahan (L) lebih gelap dibandingkan dengan perlakuan 60\%:40\% dan 70\%:30\% yaitu 41,8. Hal tersebut terjadi karena adanya peningkatan suhu pemanasan pati sehingga kadar amilosa dan kecerahan Cilok menurun. Amilosa yang sudah terbentuk mengalami depolimerisasi pada pemanasan suhu tinggi sehingga amilosa memiliki bobot molekul rendah (Yuliasih, dkk., 2007).

\subsubsection{Tingkat Kemerahan (+a)}

\subsection{Cilok Kering Rasio Tepung Tapioka dan ISP}


Nilai rerata tingkat kemerahan $(+a)$ cilok kering rasio tepung tapioka dan ISP tertinggi adalah perlakuan dari rasio 50\%:50\% yaitu 19,9 dan nilai rerata tingkat kemerahan $(+a)$ terendah adalah perlakuan dari rasio 100\%:0\% yaitu 16,4. Semakin tinggi penggunaan ISP pada adonan Cilok maka semakin tinggi tingkat kemerahan Cilok kering. Warna kemerahan pada Cilok kering hasil penelitian perlakuan dari tepung tapioka dan ISP berasal dari antosianin yang terdapat dalam ISP. Antosianin dapat memberikan pigmen warna mulai dari merah, biru, hitam sampai ke ungu (Pertiwi, dkk. 2013).

\subsection{Cilok Kering Setelah Direhidrasi Rasio Tepung Tapioka dan ISP}

Nilai rerata tingkat kemerahan (+a) tertinggi adalah 16,6 yaitu hasil perlakuan dari rasio 50\%:50\% dan nilai rerata tingkat kemerahan $(+a)$ terendah adalah 12,4 yaitu hasil perlakuan dari rasio 100\%:0\%. Semakin tinggi penggunaan ISP pada adonan Cilok maka semakin tinggi tingkat kemerahan Cilok kering setelah direhidrasi. Warna pada Cilok kering setelah direhidrasi hasil penelitian perlakuan dari tepung tapioka dan ISP didapatkan dari kandungan antosianin pada ISP. Antosianin ini dapat memberikan pigmen warna mulai dari merah, biru, hitam sampai ke ungu (Pertiwi, dkk. 2013).

\subsubsection{Tingkat Kekuningan (+b)}

\subsection{Cilok Kering Rasio Tepung Tapioka dan ISP}

Nilai rerata tingkat kekuningan (+b) tertinggi adalah hasil perlakuan dari rasio 60\%:40\% yaitu 25,2 dan nilai rerata terendah tingkat kekuningan ( $+\mathrm{b})$ adalah hasil perlakuan dari rasio 100\%:0\% yaitu 19,2. Semakin tinggi penggunaan ISP pada adonan Cilok maka semakin tinggi tingkat kekuningan Cilok kering. Warna kekuningan pada cilok kering hasil penelitian perlakuan dari tepung tapioka dan ISP berasal dari karotenoid yang terkandung dalam ISP. Karotenoid dapat memberikan pigmen warna kuning, jingga hingga merah (Akbar, 2010; Maleta, dkk., 2018).

\subsection{Cilok Kering Setelah Direhidrasi Rasio Tepung Tapioka dan ISP}

Nilai rerata tingkat kekuningan (+b) tertinggi adalah 21,2 yaitu hasil perlakuan dari rasio 70\%:30\% dan nilai rerata tingkat kekuningan (+b) terendah adalah 15,4 yaitu hasil perlakuan dari rasio 100\%:30\%. Tingkat kekuningan Cilok kering setelah direhidrasi hasil penelitian perlakuan dari rasio tepung tapioka dengan ISP dipengaruhi oleh kandungan karotenoid pada ISP. Karotenoid dapat memberikan pigmen warna kuning, jingga hingga merah (Akbar, 2010; Maleta, dkk., 2018).

\subsubsection{Tekstur}

\subsubsection{Kekerasan (Hardness)}

Tingkat kekerasan (hardness) Cilok kering rasio tepung tapioka dan ISP tertinggi adalah perlakuan dari 100\%:0\% yaitu 18,943 Kgf · Tingkat kekerasan (hardness) Cilok kering rasio tepung tapioka dan ISP terendah adalah perlakuan dari rasio 70\%:30\% dan 60\%:40\% yaitu 11,943 Kgf dan 12,078 Kgf. Tekstur Cilok kering hasil penelitian perlakuan dari rasio tepung tapioka dengan ISP 70\%:30\%, 60\%:40\%, 50\%:50\%, 80\%:20\% dan 100\%:0\% terjadi gel yang saling menjerat antara karbohidrat dan protein. Tetapi cilok kering rasio tepung tapioka dan 
ISP 70\%:30\% dan 60\%:40\% diduga terjadi gel saling menjerat paling optimal sehingga membentuk rongga udara yang merata diseluruh bagian dan mengakibatkan teksturnya menjadi cenderung lunak dibandingkan yang lain. Menurut Oankenfull, dkk. (1997) jika dua polimer karbohidrat dan protein berinteraksi, dapat membentuk jaringan gel yang saling menjerat (gel interpenetrating network). Selain itu, hal ini diduga jika penggunaan ISP ditambah atau dikurangi maka terjadi interaksi parsial antar protein dan antar karbohidrat.

\subsubsection{Kekenyalan (Springiness)}

Tingkat kekenyalan (springiness) Cilok kering setelah direhidrasi tertinggi adalah 1,22 $\mathrm{mm}$ yaitu hasil perlakuan dari rasio tepung tapioka dan ISP 50\%:50\%. Tingkat kekenyalan (springiness) Cilok kering setelah direhidrasi terendah adalah 0,83 $\mathrm{mm}$ yaitu hasil perlakuan dari rasio tepung tapioka dan ISP 100\%:0\%. Cilok dengan rasio tepung tapioka dengan ISP 50\%:50\% kekenyalan cendrung menurun. Hal ini diduga distribusi air selama proses rehidrasi tersebar secara tidak merata. Cilok dengan rasio tepung tapioka dan ISP 70\%:30\%, 80\%:20\% dan 60\%:40\% memberikan tingkat kekenyalan yang tidak berbeda nyata yaitu 0,$89 ; 0,89$ dan 0,88 . Hal ini disebabkan didalam ISP mengandung gugus sulfudril $(\mathrm{SH})$ yang terdapat dalam asam-asam amino metionin, sistein dan sistin (Tabel 2.1). Menurut Liu, dkk. (2015) proses pemanasan ISP terjadi konversi gugus sulfudril menjadi ikatan disulfid, hal tersebut mengakibatkan agregasi hidrofobik dan perubahan struktur protein. Kondisi tersebut mengakibatkan adanya pengembangan sifat kekuatan gel. Serta diduga distribusi air selama proses rehidrasi tersebar secara merata sehingga tekstur Cilok rasio tepung tapioka dan ISP menjadi kenyal. Cilok dengan rasio tepung tapioka dan ISP 100\%:0\% tidak berbeda nyata dengan rasio ISP 70\%:30\%, 80\%:20\% dan 60\%:40\% dan menghasilkan Cilok yang kenyal tetapi tidak elastis. Hal ini disebabkan gelatinisasi pati terjadi akibat perubahan granula pati yang melalui proses pemasanan sehingga mengalami perubahan yang irreversible yaitu rusaknya struktur semikristalin dengan hilangnya sifat birefringent dan ukuran granula semakin besar, proses tersebut akan membentuk pasta atau menandakan bahwa telah masak (Estiasih, 2018).

\subsubsection{Tingkat Kesukaan}

\subsubsection{Warna}

\subsection{Cilok Kering Rasio Tepung Tapioka dan ISP}

Tingkat kesukaan warna cilok kering rasio tepung tapioka dan ISP yang paling disukai panelis adalah yang tidak terlalu cerah dan tidak terlalu gelap, dengan perlakuan 70\%:30\% yaitu $54,29 \%$ dari total panelis. Hal ini hampir sama dengan warna cilok pada umumnya yang memiliki warna tidak terlalu cerah dan tidak terlalu gelap. Sedangkan, tingkat kesukaan warna Cilok kering yang paling tidak disukai adalah yang memiliki warna paling gelap, dengan perlakuan 60\%:40\% dan 50\%:50\% yaitu 14,29\% dari total panelis. Warna gelap pada rasio 60\%:40\% dan 50\%:50\% disebabkan oleh semakin tinggi rasio ISP maka cilok kering yang dihasilkan semakin berwarna gelap, karena adanya reaksi pencoklatan nonenzimatis atau reaksi mailard antara protein dan gula pereduksi yang ada pada pati (Winarno, 2014). Hal ini didukung oleh pendapat Asmaraningtyas (2014) bahwa makanan yang mempunyai rasa enak, bergizi dan memiliki tekstur baik belum tentu disukai oleh panelis apabila produk makanan tersebut memiliki warna yang tidak menarik atau menyimpang dari warna yang seharusnya. 


\subsection{Cilok Kering Setelah Direhidrasi Rasio Tepung Tapioka dan ISP}

Tingkat kesukaan warna Cilok kering setelah direhidrasi rasio tepung tapioka dan ISP yang paling disukai panelis adalah perlakuan 50\%:50\% yaitu 61,43\% dari total panelis yang memiliki warna tidak terlalu gelap dan tidak terlalu cerah. Tingkat kesukaan warna Cilok kering setelah direhidrasi yang paling tidak disukai adalah perlakuan dari 60\%:40\% yaitu $2,86 \%$ dari total panelis yang memiliki warna terlalu cerah dibandingkan dengan rasio 50\%:50\%. Diduga panelis terbiasa mengkonsumsi cilok pada umumnya yang memiliki warna tidak terlalu cerah dan tidak terlalu gelap. Hal ini didukung oleh pendapat Asmaraningtyas (2014) bahwa makanan yang mempunyai rasa enak, bergizi dan memiliki tekstur baik belum tentu disukai oleh panelis apabila produk makanan tersebut memiliki warna yang tidak menarik atau menyimpang dari warna yang seharusnya.

\subsubsection{Aroma}

\subsection{Cilok Kering Rasio Tepung Tapioka dan ISP}

Tingkat kesukaan aroma Cilok kering rasio tepung tapioka dan ISP yang paling disukai adalah perlakuan 70\%:30\% yaitu 34,14\% dari total panelis. Hal ini diduga karena karakteristik Cilok kering yang disukai oleh panelis adalah yang tidak dominan beraroma langu kedelai yang bersumber dari ISP. Tingkat kesukaan aroma Cilok kering yang paling tidak disukai perlakuan 100\%:0\% dan 50\%:50\% yaitu 25,71\% dari total panelis. Hal ini diduga panelis tidak suka dengan cilok yang memiliki aroma dominan khas singkong yang berasal dari tepung tapioka serta aroma khas kedelai (langu) karena adanya enzim lipoksigenase pada kedelai yang merupakan bahan utama dalam pembuatan isolat protein kedelai (Fatmala dan Adi, 2017).

\subsection{Cilok Kering Setelah Direhidrasi Rasio Tepung Tapioka dan ISP}

Tingkat kesukaan aroma Cilok kering setelah direhidrasi yang paling disukai panelis adalah perlakuan dari 100\%:0\% yaitu 55,71\% dari total. Hal ini diduga karena karakteristik Cilok kering setelah direhidrasi yang disukai oleh panelis adalah aroma yang tidak dominan aroma kedelai yang bersumber dari ISP. Tingkat kesukaan aroma Cilok kering setelah direhidrasi yang paling tidak disukai adalah perlakuan dari 60\%:40\% yaitu 2,86\% dari total panelis. Hal ini diduga cilok dengan rasio tepung tapioka dan ISP memberikan aroma khas kedelai (langu) karena adanya enzim lipoksigenase pada kedelai yang merupakan bahan utama dalam pembuatan isolat protein kedelai (Fatmala dan Adi, 2017).

\subsubsection{Tekstur}

\subsection{Cilok Kering Rasio Tepung Tapioka dan ISP}

Tingkat kesukaan tekstur Cilok kering rasio tepung tapioka dan ISP yang paling disukai adalah perlakuan 70\%:30\% yaitu 37,14\% dari total panelis yang bertekstur paling lunak, dengan tingkat kekerasan 11,943 Kgf. Tingkat kesukaan tekstur Cilok kering yang paling tidak disukai adalah perlakuan 100\%:0\% yaitu 28,57\% dari total panelis. Diduga panelis tidak suka dengan cilok kering yang memiliki tekstur paling keras karena, menurut presepsi panelis cilok kering yang paling keras apabila sudah direhidrasi teksturnya cenderung keras. Menurut Zulkarnanain (2014) tekstur yang disukai panlis pada berbagai olahan pangan adalah lunak seperti daging, kenyal seperti bakso dan renyak seperti biskuit. Tekstur suatu produk olahan 
pangan dapat diamati dengan mulut (digigit, dikunyah dan ditelan) atau mengunakan indra peraba jari.

\subsection{Cilok Kering Setelah Direhidrasi Rasio Tepung Tapioka dan ISP}

Tingkat kesukaan tekstur Cilok kering setelah direhidrasi rasio tepung tapioka dan ISP tertinggi adalah $57,14 \%$ dari total panelis yaitu hasil perlakuan dari rasio tepung tapioka dan ISP 70\%:30\% yang tingkat kekenyalannya tidak terlalu kenyal dan tidak terlalu keras dengan nilai kekenyalan 0,89 mm. Tingkat kesukaan tekstur Cilok kering setelah direhidrasi paling tidak disukai adalah perlakuan dari rasio 80\%:20\% yaitu 8,57\% dari total panelis.

\subsubsection{Rasa}

\subsection{Cilok Kering Setelah Direhidrasi Rasio Tepung Tapioka dan ISP}

Tingkat kesukaan rasa Cilok kering setelah direhidrasi paling disukai adalah perlakuan dari 100\%:0\% yaitu 55,71\% dari total panelis. Hal ini diduga karena kebiasaan panelis tingkat sekolah dasar yang biasa mengkonsumsi makanan jajanan Cilok dipasaran yang terbuat dari pati. Tingkat kesukaan rasa Cilok kering setelah direhidrasi terendah adalah $20 \%$ dari total panelis yaitu hasil perlakuan dari rasio tepung tapioka dan ISP 50\%:50\%. Diduga panelis tidak suka cilok yang memiliki rasa dominan ISP yang timbul aftertaste sedikit pahit. Rasa pahit tersebut diduga berasal dari senyawa glikosida yaitu soyaponin dan sapogenol yang terdapat pada kedelai yang merupakan bahan utama ISP (Purwanto dan Hersoelistyorini, 2011). Hal ini didukung oleh penelitian Arifandy dan Adi (2016) bahwa penambahan ISP pada pembuatan sosis tempe dapat berpengaruh terhadap aftertaste pahit pada sosis tempe.

\subsection{Waktu Rehidrasi Suhu Ruang}

Hasil pengamatan waktu rehidrasi yang diambil untuk proses perendaman adalah 6 jam karena pada waktu tersebut perlakuan Cilok sudah mencapai titik optimum dan cenderung stabil pada waktu selanjutnya.

\subsection{Waktu Rehidrasi Setelah Perendaman Pada Suhu Panas}

Hasil pengamatan waktu rehidrasi yang diambil untuk proses perendaman adalah 6 jam dan perebusan selama 10 menit pada suhu $100^{\circ} \mathrm{C}$. Perebusan pada waktu 10 menit telah mencapai titik optimal karena pati sudah tergelatinisasi secara merata, hal tersebut didukung oleh penelitian menurut penelitian Imaningsih (2012) tepung tapioka tergelatinisasi secara sempurna pada suhu $69,56^{\circ} \mathrm{C}$ selama 6,05 menit dan menurut penelitian Li (2005) isolat protein kedelai tergelatinisasi sempurna pada suhu $100^{\circ} \mathrm{C}$ selama 20 menit.

\section{Simpulan}

Rasio tepung tapioka dan ISP pada Cilok kering tidak memberikan pengaruh yang nyata terhadap kadar air, tetapi berpengaruh nyata terhadap kadar protein dan pati. Rasio tepung tapioka dan ISP pada Cilok kering berpengaruh nyata terhadap sifat fisik warna (tingkat kecerahan, kemerahan dan kekuningan). Rasio tepung tapioka dan ISP pada Cilok kering setelah direhidrasi berpengaruh nyata terhadap sifat fisik warna (tingkat kecerahan, kemerahan dan kekuningan). Tingkat kesukaan warna, aroma dan tekstur Cilok kering memiliki nilai kesukaan tertinggi pada perlakuan 70\%:30\%. Tingkat kesukaan warna Cilok 
kering setelah direhidrasi memiliki tingkat kesukaan tertinggi pada perlakuan 50\%:50\%. Aroma dan rasa memiliki tingkat kesukaan tertinggi pada perlakuan 100\%:0\%. Tekstur memiliki tingkat kesukaan tertinggi pada perlakuan 70\%:30\%. Waktu rehidrasi Cilok kering yang terbaik adalah perendaman selama 6 jam dan perebusan selama 10 menit.

\section{Daftar Rujukan}

Akbar, A. R. 2010. Hubungan Antara Kandongan Karotenoid dengan Ketahanan Benih Terhadap Pengusangan Cepat Pada Beberasa Varietas Kedelai (Glycine max (L.) Merr.) Skripsi. Bogor: Departemen Agronomi dan Hortikultura, Fakultas Pertanian, IPB

Andrew, S. R., Wiwiek, S. W., dan Subagio, A. 2006. Karakterisasi Biji dan Protein Koro Komak (Lablab purpureus (L.) Sweet) Sebagai Sumber Protein. Jurnal Teknologi dan Industri Pangan. 17 (2): 120-124.

Andriani, S. A. 2018. Perbandingan Udang Rebon (Acetes sp.) dengan Kacang Merah (Phaseolus vulgaris L.) dan Konsentrasi Tepung Tapioka dalam Pembuatan Bakso Kering Udang Rebon. Tugas akhir tidak diterbitkan. Bandung: Teknologi Pangan, Fakultas Teknik, Universitas Pasundan.

Anita. 2006. Analisis Keamanan Pangan Jajanan dan Upaya Peningkatan Mutunya (Studi Kasus Produk Cilok di Kecamatan Dramaga Kabupaten Bogor). Skripsi tidak diterbitkan. Bogor: Fakultas Teknologi Pertanian, IPB.

Arifandy, A. R. \& Adi, A. C. 2016. Pengaruh Substitusi Tempe dan Penambahan Isolated Soy Protein Terhadap Mutu Organoleptik dan Kandungan Protein Sosis Ayam. Jurnal Media Gizi Indonesia, (Online), 11 (1): 80 87, (https://https://e-journal.unair.ac.id/MGI/article/download/3067/4679).

Asmaraningtyas, D. 2014. Kekerasan, Warna dan Daya terima Biskuit yang Disubstitusi Tepung Labu Kuning. Naskah Publikasi. Surakarta: Fakultas Ilmu Kesehatan, Universitas Muhammadiyah Surakarta

Astuti, R. T., Darmanto, Y. S. dan Wijayanti, I. 2014. Pengaruh Penambahan Isolat Protein Kedelai Terhadap karakteristik Bakso dari Surimi Ikan Swangi (Priacanthus tayenus). Jurnal Pengolahan dan Bioteknologi Hasil Perikanan. 3(3):47-54.

Azizah dan Asma. 2018. Pengaruh Penggunaan Surimi Ikan Kembung (Rastrelliger Sp.) dengan Konsentrasi Isolated Soy Protein yang berbeda terhadap Karakteristik Fisika, Kimia dan Organoleptik Sosis Ikan. Thesis tidak diterbitkan. Malang: Manajemen Sumberdaya Perairan, Fakultas Perikanan dan Ilmu Kelautan, Universitas Brawijaya

Estiasih, T., Harijono., Waziiroh, E. dan Fibrianto, K. 2018. Kimia dan Fisik Pangan. Jakarta: Bumi Aksara.

Fatmala, I. A. dan Adi, A. C. 2017. Daya Terima Dan Kandungan Protein Biskuit Substitusi Tepung Ubi Jalar Ungu Dan Isolat Protein Kedelai Untuk Pemberian Makanan Tambahan Ibu Hamil. Media Gizi Indonesia. 12(2) 156-163.

Imaningsih, N. 2012. Profil Gelatinisasi Beberapa Formulasi Tepung-Tepungan Untuk Pendugaan Sifat Pemasakan. Jurnal Penel Gizi Makan. 35(1): 13-22.

Indrasti, F. 2004. Pemanfaatan Tepung Talas Belitung (Xanthosoma saginifolium) dalam Pembuatan Cookies. Skripsi Fakultas Teknologi Pertanian, Institut Pertanian Bogor. Bogor

Karl, W., and Bridget, O. 2009. Soy Protein Applications in Nutrition \& Food Technology. Urbana-Champaign: National Soybean Research Laboratory University of Illinois, (Online), (www.wishh.org/wp.../2009-KarlWeingartner-and-Bridget-Owen.pdf).

Kusnandar, F. (2010). Kimia Pangan: Komponen Makro. Dian Rakyat, Jakarta

Lestari, S. \& Adi, A. C. 2016. Penambahan Ikan Lele (Clarias gariepinus) dan Isolated Soy Protein terhadap Daya Terima dan Kadar Protein Cilok. Jurnal Gizi Indonesia, (Online), 11 (2): 160- 166, (https://www.researchgate.net publication/326685651_).

Li, W., Zhao, H., He, Z., Zeng, M., Qin, F., \& Chen, J. 2016. Modification of soy protein hydrolysates by Maillard reaction: Effects of carbohydrate chain length on structural and interfacial properties. Colloid Surface B. 138: $70^{-} 77$.

Liu, Q., Geng, R., Zhao, J., Chen, Q. dan Kong, B. 2015. Structural and Gel Textural Properties of Soy Protein Isolate When Subjected to Extreme Acid pH-Shifting and Mild Heating Processes. Journal of Agricultural and Food Chemistry. 63(19):4853-4861

Maleta, H. S., Indrawati, R., Limantara, L., Brotosudarmo, T. H. P. 2018. Ragam Metode Ekstrasi Karotenoid dari Sumber Tumbuhan dalam Dekade Terakhir. Jurnal Rekayasa Kimia dan Lingkungan. 13(1): 40- 50. 
Oakenfull D., Pearce, J. dan Burley, R. W. 1997. Protein Gelation. Infood protein and their applications. Damodaran S and Paraf A. (Edt.). Marcel Dekker. Inc. New York. Basel. Hongkong.

Pangastuti, H.A., Affandi, D.R., Ishasani, D. 2013. Karakteristik sifat fisik dan kimia tepung kacang merah dengan beberapa perlakuan pendahuluan. Jurnal Teknosains Pangan. 2(1): 20-29.

Pertiwi, S. F., Aminah, S., Nurhidajah. 2013. Aktivitas Antioksidan, Karakteristik Kimia dan Sifat Organoleptik Susu Kecambah Kedelai Hitam (Glycine Soja) Berdasarkan Variasi Waktu Perkecambahan. Jurnal Pangan dan Gizi. 4(8): 1-6.

Purwanto \& Hersoelistyorini, W. (2011). Studi Pembuatan Makanan Pendamping Asi (mp-asi) Menggunakan Campuran Tepung Kecambah Kacang Kedelai, Kacang Hijau, Dan Beras. Jurnal Pangan dan Gizi, 2(3), $43-4$.

Puteri, N. E., Astawan, M. dan Palupi, N. S. 2017. Karakteristik Tepung Tempe Larut Air. Skripsi tidak diterbitkan. Bogor: Program Studi Ilmu Pangan. Fakultas Teknologi Pertanian, IPB.

Solihat, A., Hakim. L. dan Setiawati, S. D. 2016. Strategi Produk Cilok Sebagai Makanan Khas Kota Bandung. Jurnal Ecodemica. (Online), 4 (2): 242 249, (http://ejournal.bsi.ac.id/ejurnal/index.php/ecodemica).

Suryanto, E. (2011). Pengguanaan Protein kedelai Pada Industri Olahan Daging. (Online), (http://foodreview.co.id/blog-56553-Penggunaan-Protein-Kedelai-pada-Industri-Olahan-Daging.html).

Utama, A. N. 2016. Substitusi Isolat Protein Kedelai pada Daging Analog Kacang Merah (Phaseolus vulgaris L.). Skripsi tidak diterbitkan. Semarang: Universitas Diponegoro.volvaceae).

Wicaksana, F. C., Agustin, T. W. dan Rianingsih, L. 2014. Pengaruh Penambahan Bahan Pengikat Terhadap Karakteristik Fisik Ikan Patin (Pangasius hyphyhalmus). Jurnal Pengolahan dan Bioteknologi, (Online), 3 (3): 1' 8, (http://www.ejournal-s1.undip.ac.id/index.php/jpbhp).

Widaningrum, dkk. 2005. Pengayaan Tepung Kedelai pada Pembuatan Mie Basah dengan Bahan Baku Tepung Terigu yang Disubstitusi Tepung Garut. Jurnal Pascapanen 2(1): 41- 48.

Winarno, F.G. 2004. Kimia Pangan dan Gizi. Jakarta: Gramedia Pustaka Utama.

Wiraningrum, E. A. Pudjirahayu, A., Setyobudi, S. I. 2015. Pangan Jajanan Anak Sekolah (PJAS), Kecukupan Energi dan Zat Gizi Anak Sekolah Dasar. Jurnal Informasi Kesehatan Indonesia (JIKI). 1 (1): 25 33.

Yuliasih, I., Irawadi, T.T., Sailah, I., Pranamuda, H., Setyowati K. dan Sunarti, T.C. 2007. Pengaruh Proses Fraksinasi Pati Sagu Terhadap Karakteristik Fraksi Amilosanya. Jurnal Teknologi Industri Pertanian 17(1): 29-36.

Zulkarnain, N. A. 2014. Studi Pembuatan Bakso Instan dari Ikan Gabus. Skripsi Tidak diterbitkan. Makassar: Jurusan Teknologi Pertanian, Fakultas Pertanian, Universitas Hasanuddin. 